\section{Microbiological challenge testing for Listeria monocytogenes in ready-to-eat food: a practical approach}

\author{
Carlo Spanu, Christian Scarano, \\ Michela Ibba, Carlo Pala, Vincenzo Spanu, \\ Enrico Pietro Luigi De Santis
}

Dipartimento di Medicina Veterinaria, Università degli Studi di Sassari, Italy

\section{Abstract}

Food business operators (FBOs) are the primary responsible for the safety of food they place on the market. The definition and validation of the product's shelf-life is an essential part for ensuring microbiological safety of food and health of consumers. In the frame of the Regulation (EC) No 2073/2005 on microbiological criteria for foodstuffs, FB0s shall conduct shelf-life studies in order to assure that their food does not exceed the food safety criteria throughout the defined shelf-life. In particular this is required for ready-to-eat (RTE) food that supports the growth of Listeria monocytogenes. Among other studies, FBOs can rely on the conclusion drawn by microbiological challenge tests. A microbiological challenge test consists in the artificial contamination of a food with a pathogen microorganism and aims at simulating its behaviour during processing and distribution under the foreseen storage and handling conditions. A number of documents published by international health authorities and research institutions describes how to conduct challenge studies. The authors reviewed the existing literature and described the methodology for implementing such laboratory studies. All the main aspects for the conduction of $L$. monocytogenes microbiological challenge tests were considered, from the selection of the strains, preparation and choice of the inoculum level and method of contamination, to the experimental design and data interpretation. The objective of the present document is to provide an exhaustive and practical guideline for laboratories that want to implement $L$. monocytogenes challenge testing on RTE food.

\section{Introduction}

Regulation (EC) No 852/2004 (European Commission, 2004) on the hygiene of foodstuffs states that the primary responsibility for food safety rests with the food business operators (FBOs), which are legally responsible for the determination of the date of minimum durability of the foodstuffs they place on the market. According to Regulation (EC) No 2073/2005 (European Commission, 2005) on microbiological criteria for foodstuffs, FB0s shall ensure the compliance of their products with the limits set by the Regulation until the end of the shelf-life. When defining the product shelf-life FBOs should base their decision on scientific evidences. In particular, for readyto-eat (RTE) food that support the growth of Listeria monocytogenes, the Regulation describes a series of studies that may be conducted. Among the indicated shelf-life studies are the challenge studies. Although the Regulation indicates the opportunity of conducting such studies, it does not describe how to perform them. Two main guidance documents have been published describing the methodology to conduct shelf-life studies for $L$. monocytogenes in RTE food. The first, directed to laboratories, is a technical guidance document on shelf life studies for $L$. monocytogenes in RTE food, prepared by the EU Community Reference Laboratory (CRL) for L. monocytogenes (Beaufort et al., 2014). The second document, intended for FBOs, is the Guidance document on $L$. monocytogenes shelf-life studies for RTE foods, under Regulation (EC) No. 2073/2005 of 15 November 2005 on microbiological criteria for foodstuffs (EC/DG SANCO, 2008). There are a number of existing available documents published by health authorities at international scale supporting the implementation of challenge testing as a control measure of $L$. monocytogenes in RTE foods (USFDA, 2008; Chilled Food Association, 2010; NZFSA, 2011; Health Canada, 2012; FSIS, 2014). A challenge study consists in the artificial contamination of the food with the target microorganism under controlled experimental conditions. These studies are intended to determine whether a RTE food is able to support the growth of $L$. monocytogenes or not during the designated shelf-life. A further application of challenge studies is to validate the efficacy of lethality treatment applied to RTE foods intended to reduce or eliminate the pathogen (Scott et al., 2005). Many factors should be taken into account in designing, conducting and interpreting the results of a challenge study. Some of them are related to the laboratory conditions while other are related to product formulation, manufacturing process, packaging, conditions during distribution and consumption. To neglect all these aspects could lead to flawed conclusions and invalidate the study. Therefore, the aim of the present document is to review the existing available documents and to provide FBOs, research laboratories and official control authorities with a practical guide to design and perform challenge studies for $L$. monocytogenes in RTE foods.
Correspondence: Carlo Spanu, Dipartimento di Medicina Veterinaria, Università degli Studi di Sassari, via Vienna 2,07100 , Sassari, Italy. Tel: +39.079 .229454 - Fax: +39.079 .229458 .

E-mail: cspanu@uniss.it

Key words: Listeria monocytogenes, Challenge test, Ready-to-eat.

Conflict of interests: the authors declare no potential conflict of interests.

Received for publication: 8 July 2014.

Revision received: 6 October 2014

Accepted for publication: 6 October 2014.

This work is licensed under a Creative Commons Attribution 3.0 License (by-nc 3.0).

CC Copyright C. Spanu et al., 2014

Licensee PAGEPress, Italy

Italian Journal of Food Safety 2014; 3:4518

doi:10.4081/ijfs.2014.4518

\section{Materials and Methods}

Laboratories performing challenge studies should be aware that for handling L.monocytogenes a biosafety level 2 is required and expert microbiologists are needed. Several factors must be considered when conducting a challenge study. A brief description of all the main aspects follows.

\section{Selection of $L$. monocytogenes strains}

It is usually recommended to use a pool of at least three to five different strains so that differences in growth and survival among strains are taken into account. The inoculum should include strains isolated from the processing environment or from outbreaks associated with the food being tested (Scott et al., 2005). The serotypes most frequently involved in human listeriosis (1/2a, 1/2b and 4b) should be part of the inoculum. Strains obtained from international culture collections, i.e. American Type Culture Collection (ATCC) or National Collection of Type Cultures (NCTC) can also be used. However, wild type strains are more likely to adapt and growth on the food matrix as compared to reference strains (Guyer and Jemmi, 1991; Skalina and Nikolajeva, 2010; Spanu et al., 2012, 2013). Alternatively to the use of pathogens, surrogate microorganism can be used (i.e. Listeria innocua) when the study is to be conducted into a processing facility. These microorganisms have similar characteristics with the target microorganism, except for the pathogenicity. Although it is reasonable to assume that surrogates have similar behaviour, they should be tested to demonstrate similar growth and resistance as com- 
pared with $L$. monocytogenes and for possible interaction with food formulation and background microflora (Scott et al., 2005). After the selection of the strains a genetic characterization should be conducted in order to determine if the strains recovered from the challenged samples are the same that were inoculated. This characterization could be performed with several methods such as Random Amplified Polymorphic DNA (RAPD), Amplified Fragment Length Polymorphism (AFLP), Pulsed Field Gel Electrophoresis (PFGE), DNA microarrays and gene sequencing.

\section{Preparation of the inoculum}

The procedure for the preparation of the inoculum should always start from strains stored at $-80^{\circ} \mathrm{C}$ with glycerol, avoiding subculturing of strains for more than five passages (AOAC, 2006). Streak strains onto non selective agar medium (e.g., trypticase soy agar, TSA or brain heart infusion agar, BHIA) and incubate for $24 \mathrm{~h}$ at $37^{\circ} \mathrm{C}$. Pick a single pure colony and transfer into tubes containing non selective nutrient broth (trypticase soy broth, TSB or brain heart infusion broth, BHI) and incubate at $37^{\circ} \mathrm{C}$ for a time sufficient for the strains to reach the same physiological state (late exponential phase or early stationary phase). Overnight incubation up to $36 \mathrm{~h}$, depending on the use of static or shaken incubation, is usually appropriate to obtain cells in stationary phase (ca. 1 x $10^{9}$ cells $/ \mathrm{mL}$ ). Prepare a second subculture in broth medium and incubate at refrigeration temperature for the time sufficient to reach the late exponential phase or early stationary phase. Preliminary test should be performed to determine the incubation time and enumeration confirmed by colony counting on agar plates. This phase is essential to adapt the strains when the challenge is conducted in RTE refrigerated foods. This may require also adaptation to $\mathrm{pH}$, water activity $\left(\mathrm{a}_{\mathrm{W}}\right)$ or other hostile conditions (e.g. $\mathrm{NaCl}$ concentration, preservatives) characteristic of the tested food. The preparation of each of the strains to be mixed in the inoculum should be performed separately. Once adapted, mix individual cultures in equal volume to obtain a working stock solution, which will be used, after appropriate dilution, for the contamination of the product.

\section{Inoculum level}

Prepare adequate serial dilutions in phosphate buffered saline (PBS) or sterile saline solution $(0.85 \% \mathrm{NaCl})$ to obtain the desired level of contamination.The level of the inoculum to be used depends on the objective of the study. If we were to determine the growth of $L$. monocytogenes or the stability of a product formulation, it is usually recommended to obtain a final concentration between $10^{2}-10^{3} \mathrm{cfu} / \mathrm{g}$ of product (USFDA, 2001; Uyttendaele et al., 2004; Scott et al., 2005; Beaufort et al., 2014;
NACMCF, 2010; Augustin et al., 2011). Although natural contamination of most foods in generally lower, this level allows enumeration of $L$. monocytogenes. In some circumstances lower levels can also be used but in this case the detection limit of the enumeration method should be increased, by using duplicate plates (e.g. $2 \mathrm{~mL}$ of the suspension onto 6 plates) or by using the most probable number (MPN) method (NACMCF, 2010; Corry et al., 2010). Failure to enumerate $L$. monocytogenes could lead to the incorrect conclusion that the product is safe. On the other hand, if too high of an inoculum level is used, the microorganisms may overcome the ability of the product formulation to inhibit $L$. monocytogenes growth. Instead, the validation of a lethal treatment requires higher inoculum levels. This depends on the extent of reduction we desire to validate. Inoculum levels of approximately $10^{5}-10^{7} \mathrm{cfu} / \mathrm{g}$ of product are generally suggested (USFDA, 2001; Scott et al., 2005; NACMCF, 2010). According to the Listeria Rule issued by the Food Safety and Inspection Service (FSIS) the validation of a post-lethality treatment should demonstrate at least 1-log reduction of $L$. monocytogenes to be considered effective (FSIS, 2003), but higher levels of inactivation can be demonstrated according to circumstances. The Codex Alimentarius Commission (2004) defined the effect on the frequency and/or concentration in a food that must be achieved by the application of one or more control measure to provide or contribute to a food safety objective (FSO) or adequate level of protection (ALOP), as the performance criterion (PC). Different public health risk for L. monocytogenes are accepted by international health authorities which lead to a zero tolerance policy in RTE meat products recommended by USDA, while the SCVPH of EC (2005) considered $10^{2} \mathrm{cfu} / \mathrm{g}$ a FSO at the time of consumption valid to provide an ALOP. When selecting the appropriate PC, FBOs should consider the type of food, the possible survival, growth and recontamination during the product shelf-life.

\section{Experimental design}

A number of factors should be taken into account when designing challenge studies. The duration of the study should be at least equal to the shelf-life of the product and analysis performed at least the day the product is inoculated $(\operatorname{day} 0)$ and at the end of the shelflife (day end). A sufficient number of intermediate sampling intervals (at least 4-5) should be set over time. Ideally, an additional time should be considered (1.5 times the shelf-life), to simulate the eventuality the product is consumed beyond its assigned durability (Scott $e t$ al., 2005). At each interval a minimum of 3 inoculated test units should be analyzed. Increasing the number of the units tested at each analysis point will increase the confidence of the study. Along with inoculated test units, a number of control units should be analyzed at each sampling interval. Controls are represented by uninoculated units (blank samples) used for detecting the level of natural contamination with $L$. monocytogenes, the background microflora and physical-chemical characteristics of the product. The determination of the background microflora is essential in order to evaluate possible interaction that may affect the growth of $L$. monocytogenes. The physical-chemical properties of the product (i.e. $\mathrm{a}_{\mathrm{w}}$, moisture, salt level, $\mathrm{pH}$, preservatives levels, gas concentrations in Modified Atmosphere Packaging, etc.) should be monitored through the shelf life to account for factors that may affect the growth or inactivation rate of $L$. monocytogenes. As far as sample size, duplicate or triplicate sample units should be tested at each interval point. The study should be ideally repeated in three independent trials using three different batches of the same product so that product variation is considered (Scott et al., 2005; Beaufort et al., 2014).

\section{Inoculation method}

The inoculation procedure should be performed in such a way that product formulation is not changed. Therefore, the inoculum volume should not exceed $1 \%$ of the product weight or volume. For products that are packaged in MAP the inoculation procedure shall ensure that the gas composition is similar to what is expected in the uninoculated products (Beaufort et al., 2014). Contamination should be as close as possible to natural contamination. Liquid product can be directly inoculated with an appropriate volume of the mixed culture at the desired concentration, while solid products can be sprayed, dipped, spreaded or mixed with the inoculum. A holding period after the inoculation is needed to allow the inoculum to attach to the product (Health Canada, 2012). The level of contamination should be confirmed by testing control positive unit after the inoculation.

\section{Food product storing conditions}

After the artificial contamination and for the entire duration of the study the products should be packaged under the same condition as intended for marketing (under vacuum, modified atmosphere, etc.). The temperature should mimic the foreseen conditions of the product during storage and distribution (e.g. refrigerated). Although out of the control of food industries, poor consumers handling of the product during dispatch, storage and domestic usage should be taken into account. Therefore, temperature abuse in the distribution chain could also be simulated by incubating the food at temperatures above the refrigeration temperature. The time and the temperature used should be justified by detailed infor- 
mation: the $75^{\text {th }}$ percentile of the observation for the country where the stage of cold chain is located (Beaufort et al., 2014).

\section{Samples analysis}

The detection and enumeration of $L$. monocytogenes should be conducted according to standard methods (ISO 11290-1:1996 and ISO 11290-2:1998; ISO, 1996, 1998) as stated in the Regulation No. 2073/2005. When the study is aimed to evaluate the efficacy of a lethality step, it is required to use an enrichment method in order to detect $L$. monocytogenes that may be no longer recovered with the enumeration method. Inoculated units should be analyzed at day 0 , day end and at all intermediate points for the enumeration of $L$. monocytogenes. Non-inoculated units should also be analyzed at the same intervals by the detection method. When assessing the lethality of a killing steps (e.g. heath treatment, high pressure), detection and enumeration method should be conducted on treated units after (the same day) the delivery of the lethal treatment. The lethal treatment may not kill all Listeria cells that may survive in the product. Such injured cells may repair themselves and recover their ability to growth, being as dangerous as uninjured cells. However, sublethally injured cells may not be cultured on selective media due to the presence of antibiotics, organic dyes and other selective agents. Therefore, testing foods after heat treatment requires techniques that enable to detect sublethally injured cells. Although the use of non selective media on one hand allows the recovery of damaged cells, on the other hand cannot differentiate the target microorganism from background microflora. The Thin Agar Layer (TAL) method is a method which consists in the overlay of a nonselective agar medium onto agar plates containing a selective medium that combines the ability to enumerate and to differentiate heat injured cells (Kang and Fung, 1999; Wu and Fung, 2001). Determination of the relevant physical-chemi- cal characteristic $\left(\mathrm{pH}, \mathrm{a}_{\mathrm{w}}\right.$, salt content, preservatives concentration) that can affect the inactivation or growth of Listeria monocytgenes should be evaluated over product shelf-life. To take into account the variability of product formulation, when performing challenge study the formulation that is the most permissive for Listeria growth should be tested. Standard methods should be used when conducting the analysis. Gas composition should be monitored in product that are MAP packed to check if their concentration is stable throughout the entire shelf-life. In Table 1 an example of experimental design with the test units, sampling point and analysis to be conducted when performing a challenge study is reported. Testing for background microflora in control units gives important indication of their effect on the shelf-life of the product. The presence of starter (i.e. lactic acid bacteria) can compete with $L$. monocytogenes limiting its growth, while other contaminant microorganisms can spoil the product before $L$. monocytogenes could grow to risk levels.

\section{Results}

\section{Assessing growth potential}

The growth potential $(\delta)$ is defined as the difference between the $\log _{10} \mathrm{cfu} / \mathrm{g}$ at the end of the test and the $\log _{10} \mathrm{cfu} / \mathrm{g}$ at the beginning of the test (Beaufort et al., 2014). The $\log _{10} \mathrm{cfu} / \mathrm{g}$ at day 0 and the $\log _{10} \mathrm{cfu} / \mathrm{g}$ at day end are obtained taking the median of the $\log _{10} \mathrm{cfu} / \mathrm{g}$ concentration among the test units at the beginning and at the end of the study, respectively. Their difference is computed independently for each batch. The maximum difference between these values is the growth potential. A food is considered able to support the growth of $L$. monocytogenes if the $\delta$ is higher than 0.5 $\log _{10} \mathrm{cfu} / \mathrm{g}$, while it is assumed that the food is not able to support the growth if the $\delta$ is lower than $0.5 \log _{10} \mathrm{cfu} / \mathrm{g}$. In Table 2 a selection of studies assessing the growth potential of $L$. monocytogens obtained in different RTE food after artificial contamination is reported.

\section{Assessing lethality}

In this case it is not always necessary to analyze inoculated units at each sampling point. Since the objective is to validate the lethality of a process it is necessary to examine

Table 1. Experimental design indicating the type of analysis, the testing time and the relative minimum number of test units to perform per batch.

\begin{tabular}{llllllll}
\hline Analysis & \multicolumn{7}{c}{ Testing time } \\
& & $\mathrm{T}_{0}$ & $\mathrm{~T}_{1}$ & $\mathrm{~T}_{2}$ & $\mathrm{~T}_{\mathrm{n}}$ & $\mathrm{T}_{\text {end }}$ \\
Detection and enumeration of L. monocytogenes & $\mathrm{IU}$ & 3 & 3 & 3 & 3 & 3 \\
& $\mathrm{NC}$ & 3 & 3 & 3 & 3 & 3 \\
& $\mathrm{BS}$ & 3 & - & - & - & - \\
Background microflora & $\mathrm{NC}$ & 3 & 3 & 3 & 3 & 3 \\
& $\mathrm{BS}$ & 3 & 3 & 3 & 3 & 3 \\
\hline Physico-chemical characteristics & $\mathrm{NC}$ & 3 & 3 & 3 & 3 & 3 \\
& $\mathrm{BS}$ & 3 & 3 & 3 & 3 & 3 \\
\hline
\end{tabular}

IU, units inoculated with Listeria monocytogenes; $\mathrm{NC}$, negative control, inoculated with sterile physiological water; BS, uninoculated blank samples.

Table 2. Examples of studies aimed to assess the growth potential in different ready-to-eat food artificially contaminated with Listeria monocytogenes.

\begin{tabular}{|c|c|c|c|c|c|c|c|}
\hline Type of food & RTE food & $\mathrm{pH}$ & $A_{w}$ & Incu & & Growth & Reference \\
\hline & & & & Temperature $\left({ }^{\circ} \mathrm{C}\right)$ & Time (days) & $\left(\log _{10} \mathrm{cfu} / \mathrm{g}\right)$ & \\
\hline Meat products & Cooked ham slices & 6.2 & 0.975 & 7 & 5 & 2.0 & Uyttendaele et al., 2004 \\
\hline & Sliced deli meat & $6.1-6.3$ & - & 7 & 35 & 7.0 & Beumer et al., 1996 \\
\hline Dairy products & Ricotta salata cheese & $5.8-6.3$ & $0.940-0.950$ & $4-6$ & 60 & $3.05-4.87$ & Spanu et al., 2012 \\
\hline Fishery products & Smoked salmon & $5.8-6.3$ & $0.93-0.96$ & $4-10$ & 30 & $2.5-4.5$ & Guyer and Jemmi, 1991 \\
\hline & Salmon preparations & - & 0.997 & $4-8$ & 7 & $1.3-6.42$ & Midelet-Bourdin et al., 2010 \\
\hline Produce and salads & RTE vegetables & $6.2-7.2$ & - & $7-15$ & 6 & $0.21-3.34$ & Sant'Ana et al., 2012 \\
\hline & Green leafy vegetables & - & - & $7-10$ & - & $0.5-1.5$ & Carlin and Nguyen-The, 1994 \\
\hline & Garlic cheese salad & 5.5 & - & $3-7$ & 2 & $0.44-0.99$ & Skalina and Nikolajeva, 2010 \\
\hline & Smoked ham salad & $5.0-5.1$ & - & $3-7$ & 2 & $0.26-1.11$ & Skalina and Nikolajeva, 2010 \\
\hline & Shrimp-tomato salad & 5.5 & - & $3-7$ & 2 & $0.48-0.64$ & Skalina and Nikolajeva, 2010 \\
\hline
\end{tabular}

RTE, ready-to-eat; $a_{w}$, water activity. 
the product at the start of the trial, after the process (treatment) and at the end of its designated shelf-life (end-point determination). To determine if the process is capable of deliver the required level of lethality against $L$. monocytogenes (performance standard or $D$ ), the difference between the level of $\log _{10} \mathrm{cfu} / \mathrm{g}$ after the inoculum and at the end-point is computed. As for the determination of the growth potential, the log reduction should be calculated independently for each batch. To account for a margin of safety the lowest log reduction obtained should be compared with the highest expected contamination. The result obtained can be expressed as log reduction of the target microorganism and the performance standard $D$ is the number of $\log$ reduction. FSIS require for a post-lethality treatment to be validated to demonstrate at least 1-log reduction (i.e. a $90 \%$ reduction of the pathogen), while a reduction of $5 \log$ is considered a full lethality treatment (FSIS, 2014). If microbiological challenge testing fails to demonstrate the predetermined level of $D$, the study is not invalid, a lower $D$ can still be validated. In Table 3 a selection of studies assessing the effectiveness of thermal pasteurization, irradiation and high-pressure decontamination technologies applied on different RTE food artificially contaminated with L. monocytogenes is reported.

\section{Discussion}

Microbiological challenge tests are a tool aimed to simulate the behavior of pathogens or spoilage microorganisms on a food during processing and distribution under the foreseen storage and handling conditions. They consist in laboratory based study in which the food is artificially contaminated with a known initial concentration of the target microorganism. Microbiological challenge study can be used to determine whether or not a food supports the growth of pathogenic microorganism or as performance criterion of a process intended to deliver a lethal effect. It is worth conducting challenge studies on RTE food when their formulation does not guarantee to prevent the growth of the microorganism during the designated shelf-life. The increased demand of minimally processed RTE food poses a special attention in the definition of their shelf- life. In fact, these foods are generally characterized by mild heat treatment, minimal preservatives concentration in the formulation and storage at refrigeration temperatures. This may be inadequate to kill or to prevent the growth of an important pathogenic microorganism such as L. monocytogenes (Peck, 2006). Furthermore, the risk of listeriosis associated with RTE food is increased by the always more extended shelf-life required by the market, giving the opportunity to $L$. monocytogenes of growing to levels exceeding the limit set by health authorities. The definition of the durability of RTE foods should be based on studies aimed to assess the ability of L. monocytogenes to growth or to survive in the product under the foreseen storage condition for the entire shelf-life. Durability studies, assessing the growth of $L$. monocytogenes in naturally contaminated foods, can also be conducted. Although more realistic, the drawbacks of durability studies are that the interpretation of the results is complicated by the probability of testing contaminated food samples (which depends by the prevalence of the contamination), the low level and the uneven distribution of the initial contamination. As an example of

Table 3. Examples of studies aimed to assess the efficacy of different post-lethality treatment on Listeria monocytogenes counts applied in artificially contaminated ready-to-eat food.

\begin{tabular}{|c|c|c|c|c|c|}
\hline Type of treatment & Type of product & RTE food & Parameter & $\begin{array}{l}\text { Performance } \\
\text { standard } \Delta^{\circ} \\
\left(\log _{10}\right)\end{array}$ & Reference \\
\hline $\begin{array}{l}\text { Hot water bath } \\
\text { temperature }\left({ }^{\circ} \mathrm{C}\right)\end{array}$ & Dairy products & $\begin{array}{l}\text { Sliced deli meat } \\
\text { Sliced deli meat } \\
\text { Deli meat } \\
\text { Cooked turkey breast } \\
\text { Ricotta salata cheese }\end{array}$ & $\begin{array}{l}65 \text { for } 10 "-5 ' \\
85 \text { for } 10 " \\
90.6-96.1 \text { for 2'-10' } \\
96 \text { for 50' } \\
90 \text { for } 90 \text { ' }\end{array}$ & $\begin{array}{l}>6.0 \\
2.0-4.0 \\
7 \\
6\end{array}$ & $\begin{array}{l}\text { McCormick et al., 2003; } \\
\text { Selby et al., 2006; } \\
\text { Mangalassary et al., } 2008 \\
\text { McCormick et al., } 2003 \\
\text { Muriana et al.,2002 } \\
\text { Murphy et al., 2003b } \\
\text { Spanu et al., 2013 }\end{array}$ \\
\hline $\begin{array}{l}\text { Steam pasteurization } \\
\text { temperature }\left({ }^{\circ} \mathrm{C}\right)\end{array}$ & Meat products & $\begin{array}{l}\text { Fully cooked frankfurters } \\
\text { Fully cooked bologna logs } \\
\text { Fully cooked chicken leg quarters }\end{array}$ & $\begin{array}{l}100 \text { for } 1.5^{\prime \prime} \\
100 \text { for } 2.5^{\prime} \\
96 \text { for } 22\end{array}$ & $\begin{array}{l}3.0 \\
2.0 \\
7\end{array}$ & $\begin{array}{l}\text { Murphy et al., 2005b, } 2006 \\
\text { Murphy et al., 2005a } \\
\text { Murphy et al., 2003a }\end{array}$ \\
\hline $\begin{array}{l}\text { Electron beam irradiation } \\
\text { (kGy) }\end{array}$ & $\begin{array}{l}\text { Meat products } \\
\text { Fishery products }\end{array}$ & $\begin{array}{l}\text { RTE deli meat } \\
\text { Cold-smoked salmon }\end{array}$ & $\begin{array}{l}1.0-2.5 \\
1.0-1.5\end{array}$ & $\begin{array}{l}2.0-3.0 \\
2.5-3.0\end{array}$ & $\begin{array}{l}\text { Foong et al., 2004; Cabeza et al., } 2007 \\
\text { Su et al., 2004; Medina et al., } 2009\end{array}$ \\
\hline Gamma irradiation (kGy) & $\begin{array}{l}\text { Meat products } \\
\text { Dairy products } \\
\text { Fishery products } \\
\text { Produce }\end{array}$ & $\begin{array}{l}\text { Frankfurters } \\
\text { RTE deli meat } \\
\text { Cured ham } \\
\text { Feta cheese } \\
\text { Seafood salad } \\
\text { Chopped romaine lettuce }\end{array}$ & $\begin{array}{l}0.49-2.6 \\
0.52-2.5 \\
0.75-0.90 \\
2.5 \\
0.7 \\
0.56\end{array}$ & $\begin{array}{l}1.0-5.0 \\
1.0-5.0 \\
>2.0 \\
3.0 \\
>2.0 \\
2.6-2.9\end{array}$ & $\begin{array}{l}\text { Sommers and Thayer, 2000; Knight et al., } 2007 \\
\text { Zhu et al., 2005; Jin et al., } 2009 \\
\text { Fu et al., 1995 } \\
\text { Konteles et al., } 2009 \\
\text { Foley et al., 2005 } \\
\text { Mintier and Foley, } 2006\end{array}$ \\
\hline $\begin{array}{l}\text { High pressure } \\
\text { processing }(\mathrm{MPa})\end{array}$ & Meat products & $\begin{array}{l}\text { Frankfurters } \\
\text { RTE deli meat } \\
\text { Dry-cured ham } \\
\text { RTE deli meat } \\
\text { Gorgonzola cheese } \\
\text { Cheese } \\
\text { Cold-smoked salmon }\end{array}$ & $\begin{array}{l}300 \\
400-450 \text { for } 10^{\prime} \text { at } 12-17^{\circ} \mathrm{C} \\
600 \text { for } 5 \text { ' at } 15^{\circ} \mathrm{C} \\
600-700 \text { for } 3-10^{\prime} \text { at } 10-31^{\circ} \mathrm{C} \\
400 \text { for } 90^{\prime \prime} \text { at } 20^{\circ} \mathrm{C} \\
500 \text { for } 110^{\prime \prime} \text { at } 5-20^{\circ} \mathrm{C} \\
600 \text { for } 10^{\prime} \text { or } 700 \text { for } 5^{\prime} \\
450 \text { for } 10^{\prime} \text { at } 12^{\circ} \mathrm{C}\end{array}$ & $\begin{array}{l}1.0 \\
1.1-3.4 \\
3.85 \\
3.0-3.5 \\
2 \\
5 \\
2.0 \\
3 \\
\end{array}$ & $\begin{array}{l}\text { Lucore et al., 2000 } \\
\text { Morales et al., 2006; Marcos et al., } 2008 \\
\text { Hereu et al., } 2012 \\
\text { Hayman et al., 2004; Jofré et al., 2008, } 2009 \\
\text { López-Pedemonte et al., } 2007 \\
\text { López-Pedemonte et al., } 2007 \\
\text { Carminati et al.,2004 } \\
\text { Medina et al., } 2009\end{array}$ \\
\hline
\end{tabular}

RTE, ready-to-eat. ${ }^{\circ} \log _{10}$ reduction after the application of the treatment. 
the relationship existing between prevalence of microbial contamination of food and the potential for recovery, the number of test units needed to detect one or more positive per lot with $95 \%$ confidence level is 4 when the prevalence of contamination is $100 \%$, while it increases to 299 when the prevalence is $1 \%$ (Midura and Bryant, 2001). On the other hand, challenge studies allow knowing the initial contamination level and need lower samples units to draw conclusions. However, the results are valid only for food and for the particular conditions tested. If any significant change occurs in the product formulation or in the process, the study should be repeated.

\section{Conclusions}

Challenge studies needs the support of an expert food microbiologist and should not be performed in the microbiology laboratory of the food processing plant. A well designed challenge study can be of great support for FBOs in validating lethal treatments or product formulation aimed to control survival or growth of $L$. monocytogenes for the entire shelf-life. A proper definition of the fate of $L$. monocytogenes through the processing, distribution and successive handling of RTE food is essential in order to comply with all applicable legislative and regulatory requirements. When validating the effect of an antimicrobial agent or process it should be pointed that these strategies are aimed control $L$. monocytogenes contamination in post-lethality exposed products (e.g. slicing, curing, packaging and other unit operations conducted after the lethality step). Therefore they should not be considered as an alternative to the implementation of proper sanitation and preventive hygienic measures.

\section{References}

AOAC, 2006. AOAC International guidelines for laboratories performing microbiological and chemical analyses of food and pharmaceuticals. Association of Official Analytical Chemists, Washington, DC, USA.

Augustin JC, Bergis H, Midelet-Bourdin G, Cornu M, Couvert 0, Deni C, Huchet V, Lemonnier S, Pinon A, Vialette M, Zuliani V, Stahl V, 2011. Design and challenge testing experiments to assess the variability of Listeria monocytogenes growth in foods. Food Microbiol 28:746-54.

Beaufort A, Cornu M, Bergis H, Lardeux AL, Lombard B, 2014. EURL Lm Technical guidance document for conducting shelf- life studies on Listeria monocytogenes in ready-to eat foods. Version 3. Community Reference Laboratory for Listeria monocytogenes. Available from: http://www.fsai.ie/uploadedFiles/EURL\%20 Lm_Technical\%20Guidance\%20Document \%20Lm\%20shelf-life\%20studies_V3_201406-06\%20(2).pdf

Beumer RR, Te Giffel MC, De Boer E, Rombouts FM, 1996. Growth of Listeria monocytogenes on sliced cooked meat products. Food Microbiol 13:333-40.

Cabeza MC, Cambero I, de la Hoz L, Ordóñez JA, 2007. Optimization of E-beam irradiation treatment to eliminate Listeria monocytogenes from ready-to-eat (RTE) cooked ham. Innov Food Sci Emerg 8:299-305.

Carlin F, Nguyen The C, 1994. Fate of Listeria monocytogenes on four types of minimally processed green salads. Lett Appl Microbiol 18:222-6.

Carminati D, Gatti M, Bonvini B, Neviani E, Mucchetti G, 2004. High-pressure processing of Gorgonzola cheese: influence on Listeria monocytogenes inactivation and on sensory characteristics. J Food Protect 67:1671-5.

Chilled Food Association, 2010. Shelf life of ready-to-eat food in relation to L. monocytogenes. Guidance for food business operators. Available from: http://www.chilledfood.org/MEDIA/NEWS/2010/New+Shelf $+\mathrm{L}$ ife+Guidance+for+Ready+to+Eat+Foods

Codex Alimentarius Commission, 2004. Report of the twentieth session of the Codex Committee on General Principles, Paris, France, 3-7 May 2004, ALINORM 04/27/33A, Appendix II, pp. 37-38. Available from: http://www.codexalimentarius. org/input/download/report/618/al0433ae.pd $\mathrm{f}$

Corry JEL, Jarvis B, Hedges, AJ, 2010. Minimising the between-sample variance in colony counts on foods. Food Microbiol 27:598-603.

EC/DG SANCO, 2008. Commission staff working document Guidance document on Listeria monocytogenes shelf-life studies for ready-to-eat foods, under Regulation (EC) No. 2073/2005 of 15 November 2005 on microbiological criteria for foodstuffs. Available from: http://www.fsai.ie/uploadedFiles/EU_Guida nce_listeria_monocytogenes.pdf

European Commission, 2004. Regulation of the European Parliament and of the Council of 29 April 2004 on the hygiene of foodstuffs, 852/2004/CE. In: Official Journal, L 226/3, 25/06/2004.

European Commission, 2005. Regulation of the European Parliament and of the Council of 15 November 2005 on microbiological criteria for foodstuffs, 2073/2005/CE. In: Official Journal, L 338/1,
$22 / 12 / 2005$.

Foley DM, Trimboli SL, Lamb J, Gogley J, Thompson J, Caporaso F, Calicchia M, Prakash A, 2005. Acid-adaptation does not increase the resistance of Listeria monocytogenes to irradiation in a seafood salad. Int J Food Microbiol 99:147-56.

Foong, SC, Gonzalez GL, Dickson JS, 2004. Reduction and survival of Listeria monocytogenes in ready-to-eat meats after irradiation. J Food Protect 67:77-82.

FSIS, 2003. 9 CFR part 430, Control of Listeria monocytogenes in post-lethality exposed ready-to-eat products. United States Department of Agriculture. Available from: http://www.fsis.usda.gov/OPPDE/rdad/FRP ubs/97-013F.htm

FSIS, 2014. Compliance guideline: controlling Listeria monocytogenes in post-lethality exposed ready-to-eat meat and poultry products. United States Department of Agriculture. Available from: http://www.fsis.usda.gov/wps/wcm/conn e ct/d $3373299-50$ e 6-47 d 6 - a 577 e74ale549fde/Controlling_LM_RTE_Guid eline 0912?MOD=AJPERES

Fu AH, Sebranek JG, Murano EA, 1995. Survival of Listeria monocytogenes and Salmonella typhimurium and quality attributes of cooked pork chops and cured ham after irradiation. J Food Sci 60:10015.

Guyer S, Jemmi T, 1991. Behavior of Listeria monocytogenes during fabrication and storage of experimentally contaminated smoked salmon. Appl Environ Microb 57:1523-7.

Hayman MM, Baxter I, Oriordan PJ, Stewart $\mathrm{CM}, 2004$. Effects of high-pressure processing on the safety, quality, and shelf life of ready-to-eat meats. J Food Protect 67:1709-18.

Health Canada, 2012. Listeria monocytogenes challenge testing of refrigerated ready-toeat foods. Bureau of Microbial Hazards, Food Directorate, Health Products and Food Branch. Available from: h t t p ://ww w. h c - s c.g c . c a/f n an/alt_formats/pdf/legislation/pol/listeria_monocytogenes-test-eng.pdf

Hereu A, Bover-Cid S, Garriga M, Aymerich T, 2012. High hydrostatic pressure and biopreservation of dry-cured ham to meet the food safety objectives for Listeria monocytogenes. Int J Food Microbiol 154:107-12.

ISO, 1996. Microbiology of food and animal feeding stuffs-horizontal method for the detection and enumeration of Listeria monocytogenes. Part 1: Detection method. ISO Norm 11290-1. International Standardization Organization ed., Geneva, Switzerland.

ISO, 1998. Microbiology of food and animal feeding stuffs-horizontal method for the 
detection and enumeration of Listeria monocytogenes. Part 2: Enumeration method. ISO Norm 11290-2. International Standardization Organization ed., Geneva, Switzerland.

Jin T, Liu L, Sommers CH, Boyd G, Zhang H, 2009. Radiation sensitization and postirradiation proliferation of Listeria monocytogenes on ready-to-eat deli meat in the presence of pectin-nisin films. J Food Protect 72:644-9.

Jofré A, Aymerich T, Grèbol N, Garriga M, 2009. Efficiency of high hydrostatic pressure at $600 \mathrm{MPa}$ against food-borne microorganisms by challenge tests on convenience meat products. LWT-Food Sci Technol 42:924-8.

Jofré A, Garriga M, Aymerich T, 2008. Inhibition of Salmonella sp. Listeria monocytogenes and Staphylococcus aureus in cooked ham by combining antimicrobials, high hydrostatic pressure and refrigeration. Meat Sci 78:53-9.

Kang DH, Fung DY, 1999. Thin agar layer method for recovery of heat-injured Listeria monocytogenes. J Food Protect 62:1346-9.

Knight TD, Castillo A, Maxim J, Keeton JT, Miller RK, 2007. Effectiveness of potassium lactate and sodium diacetate in combination with irradiation to control Listeria monocytogenes on frankfurters. J Food Sci 72:26-30.

Konteles S, Sinanoglou VJ, Batrinou A, Sflomos K, 2009. Effects of $\gamma$-irradiation Listeria monocytogenes population, colour, texture and sensory properties of Feta cheese during cold storage. Food Microbiol 26:157-65.

López-Pedemonte T, Roig-Sagués A, De Lamo S, Hernández-Herrero, M, Guamis B, 2007. Reduction of counts of Listeria monocytogenes in cheese by means of high hydrostatic pressure. Food Microbiol 24:59-66.

Lucore LA, Shellhammer TH, Yousef AE, 2000. Inactivation of Listeria monocytogenes Scott A on artificially contaminated frankfurters by high-pressure processing. $\mathrm{J}$ Food Protect 63:662-4.

Mangalassary S, Han I, Rieck J, Acton J, Dawson P, 2008. Effect of combining nisin and/or lysozyme with in-package pasteurization for control of Listeria monocytogenes in ready-to-eat turkey bologna during refrigerated storage. Food Microbiol 25:866-70.

Marcos B, Aymerich T, Monfort JM, Garriga M, 2008. High-pressure processing and antimicrobial biodegradable packaging to control Listeria monocytogenes during storage of cooked ham. Food Microbiol 25:177-82.

McCormick K, Han IY, Acton JC, Sheldon BW, Dawson PL, 2003. D and z-values for
Listeria monocytogenes and Salmonella typhimurium in packaged low-fat ready-toeat turkey bologna subjected to a surface pasteurization treatment. Poultry Sci 82:1337-42.

Medina M, Cabeza MC, Bravo D, Cambero I, Montiel R, Ordóñez JA, Nuñez M, Hoz L, 2009. A comparison between E-beam irradiation and high pressure treatment for cold-smoked salmon sanitation: microbiological aspects. Food Microbiol 26:224-7.

Midelet-Bourdin G, Copin S, Leleu G, Malle P, 2010. Determination of Listeria monocytogenes growth potential on new fresh salmon preparations. Food Control 21: 1415-8.

Midura TF, Bryant RG, 2001. Sampling plans, sample collection, shipment, and preparation for analysis. In: F.P. Downes and K. Ito (eds.), Compendium of methods for the microbiological examinations of foods. American Public Health Association ed., Washington, DC, USA, pp 13-23.

Mintier AM, Foley DM, 2006. Electron beam and gamma irradiation effectively reduce Listeria monocytogenes populations on chopped romaine lettuce. J Food Protect 69:570-4.

Morales P, Calzada J, Nunez M, 2006. Effect of high-pressure treatment on the survival of Listeria monocytogenes Scott A in sliced vacuum-packaged Iberian and Serrano cured hams. J Food Protect 69:2539-43.

Muriana PM, Quimby W, Davidson CA, Grooms J, 2002. Postpackage pasteurization of ready-to-eat deli meats by submersion heating for reduction of Listeria monocytogenes. J Food Protect 65:963-9.

Murphy RY, Driscoll KH, Arnold ME, Marcy JA, Wolfe RE, 2003a. Lethality of Listeria monocytogenes in fully cooked and vacuum packaged chicken leg quarters during steam pasteurization. J Food Sci 68:27803.

Murphy RY, Duncan LK, Driscoll KH, Marcy JA, Beard BL, 2003b. Thermal inactivation of Listeria monocytogenes on ready-to-eat turkey breast meat products during postcook in-package pasteurization with hot water. J Food Protect 66:1618-22.

Murphy RY, Hanson RE, Duncan LK, Feze N, Lyon BG, 2005a. Considerations for postlethality treatments to reduce Listeria monocytogenes from fully cooked bologna using ambient and pressurized steam. Food Microbiol 22:359-65.

Murphy RY, Hanson RE, Johnson NR, Scott LL, Feze N, Chappa K, 2005b. Combining antimicrobial and steam treatments in a vacuum packaging system to control Listeria monocytogenes on ready to eat franks. J Food Sci 70:138-40.

Murphy RY, Hanson RE, Johnson NR, Chappa $\mathrm{K}$, Berrang ME, 2006. Combining organic acid treatment with steam pasteurization to eliminate Listeria monocytogenes on fully cooked frankfurters. J Food Protect 69:47-52.

NACMCF, 2010. Parameters for determining inoculated pack/challenge study protocols. J Food Protect 73:140-202.

NZFSA, 2011. Guidance for the control of Listeria monocytogenes in ready-to-eat foods. Part 1: Listeria management. Ministry of Agriculture and Forestry. Available from: http://www.foodsafety.govt.nz/elibrary/indu stry/control-listeria-foods/guidance-listeria-monocytogenes.pdf

Peck MW, 2006. Clostridium botulinum and the Safety of minimally heated, chilled foods: an emerging issue? J Appl Microbiol 101:556-70.

Sant'Ana AS, Igarashi MC, Landgraf M, Destro MT, Franco BD, 2012. Prevalence, populations and pheno-and genotypic characteristics of Listeria monocytogenes isolated from ready-to-eat vegetables marketed in São Paulo, Brazil. Int J Food Microbiol 155:1-9.

Scott VN, Swanson K, Frier TA, Pruett WP Jr, Sveum WH, Hall PA, Smoot LA, Brown DG, 2005. Guidelines for conducting Listeria monocytogenes challenge testing of foods. Food Protect Trend 25:818-25.

Selby TL, Berzins A, Gerrard DE, Corvalan CM, Grant AL, Linton RH, 2006 Microbial heat resistance of Listeria monocytogenes and the impact on ready-to-eat meat quality after post-package pasteurization. Meat Sci 74:425-34.

Skalina L, Nikolajeva V, 2010. Growth potential of Listeria monocytogenes strains in mixed ready-to-eat salads. Int $\mathrm{J}$ Food Microbiol 144:317-21.

Sommers CH, Thayer DW, 2000. Survival of surface inoculated Listeria monocytogenes on commercially available frankfurters following gamma irradiation. J Food Safety 20:127-37.

Spanu C, Scarano C, Spanu V, Penna, C, Virdis S, De Santis EPL, 2012. Listeria monocytogenes growth potential in Ricotta salata cheese. Int Dairy J 24:120-2.

Spanu C, Spanu V, Pala C, Virdis S, Scarano C, De Santis EPL, 2013. Evaluation of a postlethality treatment against Listeria monocytogenes on Ricotta salata cheese. Food Control 30:200-5.

Su YC, Duan J, Morrissey MT, 2004. Electron beam irradiation for reducing Listeria monocytogenes contamination on coldsmoked salmon. J Aquat Food Prod T 13:311.

USFDA, 2001. Safe practices for food processes. Microbiological safety of controlled and modified atmosphere packaging of fresh and fresh cut produce. Available from: 
http://www.fda.gov/food/foodscienceresearch/safepracticesforfoodprocesses/ucm 091368.htm

USFDA, 2008. Control of Listeria monocytogenes in refrigerated or frozen ready-toeat foods: draft guidance for industry. Center for Food Safety and Applied Nutrition, Washington, DC, USA. Available from: http://www.fda.gov/food/guid- anceregulation/guidancedocumentsregulatoryinformation/foodprocessinghaccp/uc m073110.htm

Uyttendaele M, Rajkovic A, Benos G, François K, Devlieghere F, Debevere J, 2004. Evaluation of a challenge testing protocol to assess the ability of ready-to-eat cooked meat products against growth of Listeria monocytogenes. Int $\mathrm{J}$ Food Microbiol
90:219-36.

Wu VCH, Fung DYC, 2001. Evaluation of thin agar layer method for recovery of heat injured foodborne pathogens. J Food Sci 66:580-3.

Zhu M, Du M, Cordray J, Ahn DU, 2005. Control of Listeria monocytogenes contamination in ready to eat meat products. Compr Rev Food Sci F 4:34-42. 